\title{
Evolution of Production Costs in Brazilian Sugar-Energy Sector
}

\author{
Haroldo José Torres da Silva, Pedro Valentim Marques \\ University of São Paulo, Piracicaba, Brazil
}

\begin{abstract}
In a context of low carbon economy emergence and growing demand for alternative and renewable energy sources, Brazil appears in the technological and productive vanguard of biofuels. The sugar-energy sector has a great relevance in Brazilian agribusiness; however, it has been suffering severe deterioration of its financial situation. This article presents a methodology to calculate production costs for sugarcane, sugar, and ethanol in Brazil. Besides methodological development, this paper was based on technical and economical survey for the mills and sugarcane producers. This way, the results are presented in a segmented manner for both groups. The goal is to analyze the progress of production costs in Brazilian sugar-energy sector, in 2007/2008 and 2014/2015 crop seasons, with emphasis on technical and economic indicators about raw materials, sugar, and ethanol production. There was a systematic increase in production costs over the last nine crops and decreasing trading prices of products (sugar and ethanol), implying negative economic margin. In addition to these facts, it has been identified a decrease in agricultural productivity indicators, low levels of renovation, and aging of the sugarcane plantation.
\end{abstract}

Keywords: sugarcane growers, profitability, cost of producing, sugarcane, ethanol, Brazil

\section{Introduction}

Over the last two decades, Brazilian sugarcane production presented the largest production growth since the 1950s. The prosperity environment was fostered both by the advance of sugar production, continuing the expansion started in the previous decade, as the ethanol, which experienced its highest growth rates since the apex of the National Alcohol Program-PRO-ALCOHOL (in Portuguese Próalcool) in 1980 (Brasil, 2010). In this context, Brazil is characterized depending on its competitiveness in sugarcane production, one of the main producing countries, consumers and exporters in the sugar, and ethanol markets (Satolo, 2008).

Nevertheless, after the long period of prosperity of the two previous decades, marked by an intense process of mergers and acquisitions of business groups (Siqueira \& Castro Junior, 2010) and investments of foreign groups (Pinto, 2011), the sugarcane sector is going through a period of uncertainty about future expectations. Since the global financial crisis in 2008, the sector has experienced low level of investment, which consorted with low levels of profitability resulted in a decrease in production in recent crops.

The Agribusiness System (in Portuguese: Sistema Agroindustrial) (SAG) of sugarcane is complex and the industrial processing sugarcane mills depend on capital goods and suppliers of this raw material (Neves \& Conejero, 2007). In this environment, the strategies for obtaining sugarcane by processing agricultural

Haroldo José Torres da Silva, Ph.D. candidate, University of São Paulo, Piracicaba, Brazil.

Pedro Valentim Marques, professor, University of São Paulo, Piracicaba, Brazil.

Correspondence concerning this article should be addressed to Haroldo José Torres da Silva, Travessa Dona Eugênia, 17, Piracicaba, São Paulo, 13416-218, Brazil. 
industries set up an important issue, as they are within the context of a profound institutional change during the past decades, from industry deregulation (Bastos, 2013).

In 2013, the sugarcane tillage occupied more than 10 million hectares, and the state of São Paulo accounts for about $52.97 \%$ of the planted area in the country (IBGE, 2015). The sugarcane cultivation is carried out both by own production mills of sugar and ethanol as by independent growers. Raw material commercialization between the mills and the growers follows generally standardized models of negotiation, such as the CONSECANA $^{1}$, which links the sugarcane price to the market prices of the final chain products.

The evolution of sugarcane industry in the country highlights the importance of the sugarcane grower and its competitiveness at the raw material of its own agribusiness. However, it has been observed since the 2011/2012 crop season, a deterioration of the economic margins of these agents, because increases in nominal production costs were not accompanied by sugarcane prices (Pecege, 2015). In the last crop seasons, there was a reduction in the quality of raw materials delivered, a benchmark for pricing sugarcane (expressed in kilograms of ATR per ton of sugarcane), which also resulted in a reduction of producer remuneration. Reductions in economic margins are explained due to some factors, such as lower agricultural productivity, reducing the amount of ATR contained in the raw material delivered to the processing unit and the deterioration in the kilogram price of ATR ( $\mathrm{R} / \mathrm{kgATR})$.

In recent crop seasons, the constant drop in net income from sugarcane producer made many of these agents leave the activity. In this context, the analysis of microeconomic factors based on efficiency, as highlighted by Pereira Filho (2000), is of great importance for the competitiveness explanation because of the misallocation of resources, which contributes significantly to determining the existence of negative net income.

The role of sugarcane growers has undergone considerable changes over the last decade and, as emphasized by Bastos (2013), these changes have not been adequately addressed in the literature of agriculture. At a time when the Brazilian sugar-energy sector is undergoing a process of consolidation and financial restructuring, given their economic and social importance, it is extremely important to identify the existence of scale economies in sugarcane production, and the analysis of the factors that determine it.

Regardless of the activity or segment, the marketing economic result of a certain product is measured by the difference between the selling price and its production cost, which may reflect in profit or loss in trading. This concept is especially important for products whose prices are determined directly by the consumer market, as the case of agricultural commodities such as sugar and ethanol produced from sugarcane in Brazil.

Sugarcane cultivation is done either by own sugar and ethanol production mills as by independent suppliers. According to the Ministry of Agriculture, Livestock and Supply-MAPA (Brasil, 2015), it is estimated that $60 \%$ of processed sugarcane in Brazil is produced by the growers. Raw material marketing between mills and growers follows, generally, standard models of negotiation, such as CONSECANA, which connects the sugarcane price sales to sugar and ethanol prices.

It is inserted in this context, the "Production Costs of Sugarcane, Sugar, Ethanol and Bioelectricity" survey is sponsored by Program of Continuing Education in Economics and Management (Pecege ${ }^{2}$ ) in partnership with the Brazilian Confederation of Agriculture and Livestock (CNA). Carried out since the 2007/2008 crop

\footnotetext{
1 Conselho dos Produtores de Cana-de-açúcar, Açúcar e Álcool do Estado de São Paulo. For more information: http://www.consecana.com.br/.

2 Extension group from the Department of Economics, Management and Sociology of ESALQ (Luiz de Queiroz College of Agriculture), Universityof São Paulo (USP). For more information: http://www.pecege.org.br/.
} 
season, the survey is part of the "Countryside of the Future" project, and has had the support of almost two hundred agents from mills, sugarcane growers' associations, rural unions, federations, equipment manufacturers, research centers, and inputs suppliers. Currently, the project is a reference in information dissemination regarding the sugar and ethanol profitability in sugar-energy industry.

The aim of this study is to analyze the evolution of production costs in Brazilian sugarcane industry, presented in a disaggregated form the sugarcane production costs of independent growers, as well as the raw material produced in their own areas during the period between 2007/2008 and 2015/2016 crop seasons, highlighting the technical and economic indicators of raw material, sugar, and ethanol production.

\section{Research Methods}

\section{System for Production Costs of Independent Growers' Sugarcane}

The survey about growers' sugarcane is done through "panels" which are face meetings where the participants, who are usually farmers and cooperatives technicians, associations, and unions, define consensually to modal manufacturing facility in the region in question, indicating the technical and economic factors of the current sugarcane production technological package.

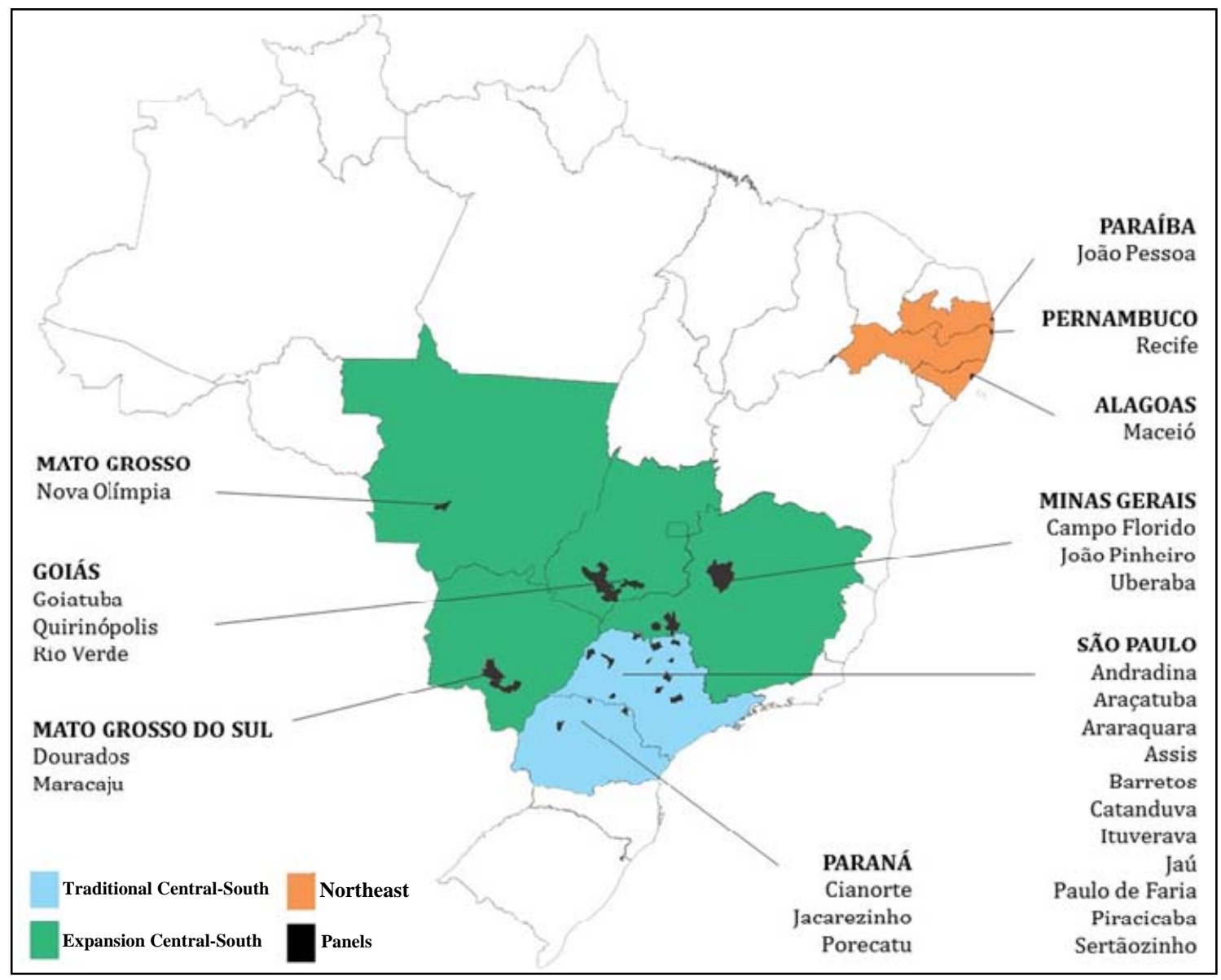

Figure 1. Growers’ sugarcane production costs survey sample.

\footnotetext{
3 Provided by CNA, it is a project that associates the rural producer to information generation for price risk management, costs and production in rural property. For more information: http://www.canaldoprodutor.com.br/.
} 
The study has 26 sample regions_-about 4.2 million hectares ${ }^{4}$ — distributed in nine different Brazilian states and in a summarized way, which are aggregated into three producing macro-regions: Traditional Central-South, Expansion South-Central and Northeast (Figure 1). The choice of sample points is made according to the distribution of sugarcane production in Brazil, and the presence of raw material suppliers in the regions. Noting also that for the costs formation of macro-regions, each panel receives a "weight", establishing different representativeness in the sample.

In terms of the panels' geographical location, the sample distribution is only a diversity indicative of sugarcane cultivation and its respective production costs. Over the surveys, it is identified several regional particularities of production, both in technical and economic terms, and it is practically impossible to establish a technological package for standard production.

Although it observed some changes in the culture mode, due to its semi-perennial cycle, sugarcane has common and well-defined production stages to different systems: formation of sugarcane (tillage, planting, and crop plant treatment) ratoon cane treatment, and harvesting. If relate the ways in which these stages are conducted-manually or mechanically-how inputs are used in production, it is possible to establish a standardized the survey matrix, as shown in Figure 2.

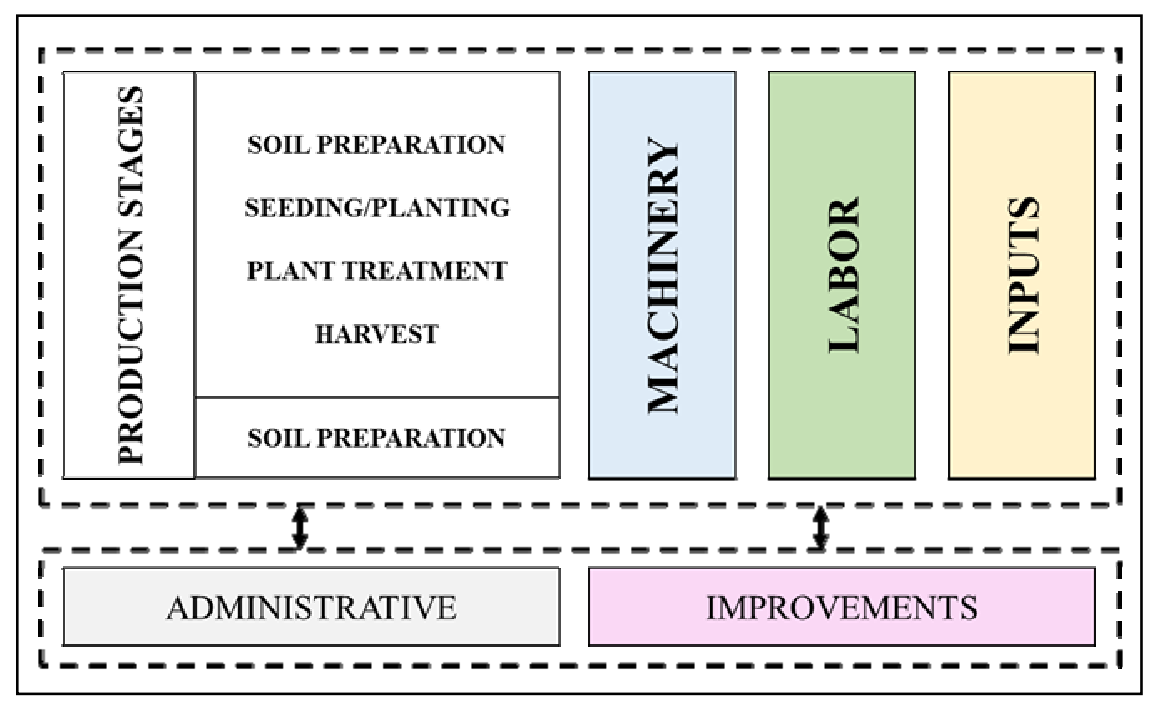

Figure 2. Survey matrix for production costs of growers' sugarcane.

As regards the cost allocation, the study takes as reference the methodology suggested by Matsunaga (1976), whose definitions are based on the production operating costs. In short, the production costs are allocated in three portions: (i) EFFECTIVE OPERATING COST (EOC) that considers all amounts disbursed directly to production, in the case of suppliers' model, such as machinery (maintenance, insurance, taxes), labor, inputs, leases, administrative expenses, and working capital financing; (ii) TOTAL OPERATING COSTS (TOC), which adds to the EOC the indirect costs with depreciation and remuneration of the owner. In the case of depreciation, as well as machinery, tools, improvements and irrigation structures, depreciation is considered as the plantation formation, since it is an investment to be amortized in subsequent years, in the case of cuts'

\footnotetext{
${ }^{4}$ Compiled from the data available by Brazilian Sugarcane Industry Association (UNICA) in UNICADATA platform (http://www.unicadata.com.br/).

${ }^{5}$ Established from the indicator "cultivated area” in micro-region level, available on IBGE and UNICA.
} 
number per stage, and (iii) TOTAL COSTS (TC), adding the capital opportunity costs invested in production. By assumption, the land remuneration is considered equal to the value of its lease, -in other words, if the producer was not producing, it could be leasing following the values of the region-and around the capital allocated to the cane field formation, machinery/implements, improvements, and irrigation structure are considered own and paid at the rate of $6 \%$ per year. It is worth noting that, in the case of common items to the plantation formation, ratoon cane treatment and harvesting, such as administrative work and machinery/implements, the values are shared between the stages so that the plots "EOC" and "TOC" do not suffer distortions in the cost distribution. To sum up, allocation costs structure is in Figure 3.

\begin{tabular}{|c|c|c|}
\hline $\begin{array}{c}\text { EFFECTIVE OPERATING } \\
\text { COST - EOC }\end{array}$ & $\begin{array}{c}\text { TOTAL OPERATING } \\
\text { COST - TOC }\end{array}$ & TOTAL COST - TC \\
\hline $\begin{array}{l}\text { - (+) Full sugarcane field } \\
\text { (Ratoon + Harvest) } \\
\text { - }(+) \text { Machinery* } \\
\text { • (-) Depreciation and } \\
\text { capital } \\
\text { - }(+) \text { Labor } \\
\text { - (+) Inputs } \\
\text { - (+) Leases } \\
\text { - (+) Administrative expenses } \\
\text { - (+) Financing working } \\
\text { capital }\end{array}$ & $\begin{array}{l}\text { - (+) EOC } \\
\text { - (+) Owner remuneration } \\
\text { - (+) Depreciation } \\
\text { - (+) Sugarcane field } \\
\text { formation* } \\
\text { - (+) Machinery } \\
\text { - (-) Depreciation and } \\
\text { capital } \\
\text { - (+) Labor } \\
\text { - (+) Inputs } \\
\text { - Machinery** } \\
\text { - Improvements } \\
\text { - Irrigation structure }\end{array}$ & $\begin{array}{c}\text { - (+) TOC } \\
\text { - (+) Land remuneration } \\
\text { - (+) Capital remuneration } \\
\text { - (+) Sugarcane field } \\
\text { formation* } \\
\text { - (-) Machinery capital } \\
\text { - (+) Machinery** } \\
\text { - (+) Improvements } \\
\text { - (+) Irrigation structure }\end{array}$ \\
\hline
\end{tabular}

Figure 3. Costs distribution for EOC, TOC and TC formation of growers' sugarcane. Notes. * Tillage + Planting + Plant Treatments; ** From tillage to harvesting; *** Values referring to operators and diesel/lubricants are allocated respectively, in labor and inputs.

\section{Cost Calculation of Industrial Production (Sugar and Ethanol)}

Costs calculation of agroindustrial production follows the methodological procedures, which are developed and described by Pecege (2015). The definitions and the fundamental concepts of this paper, based on Pecege (2015), are:

(1) The "Effective Operating Cost (EOC)" refers to the monetary amount effectively disbursed in direct production activities throughout the crop season. However "Total Operating Cost (TOC)" incorporates to these costs, the depreciation costs estimated (according to a predetermined useful life) of improvements, machinery, and equipment from the invested capital amount. Thus, the depreciations are allocated in the second portion of the cost structure, the TOC. Finally, the "Total Cost (TC)" adds to TOC capital and land remuneration, which is opportunity costs. The grouping of the main costs groups for the methodology of cost calculation implementation is summarized in Figure 4. Reiteratively, the costs of sugarcane field are classified as a depreciable investment each year, in other words, they are a component of "depreciation".

(2) The standard defined to allocate the agroindustrial processing costs of sugarcane between sugar costs (crystal or VHP) or ethanol (anhydrous or hydrous), was the apportionment of proportion of Total Reducing Sugar (TRS) used by each product. The conversion factors defined for a unit production ( $\mathrm{t}$ sugar or $\mathrm{m}^{3}$ of 
ethanol) were: white sugar 1.0474 t TRS (Northeast) and 1.0495 (Central-South), VHP sugar 1.0442 t TRS (Northeast) and 1.0453 (Central-South), anhydrous ethanol 1.5357 t TRS, and hydrous ethanol 1.4575 t TRS. For calculation of industrial productivity, the conversion factors are added to the "common industrial losses", "fermentation yields", and "distillation yields".

(3) The value used for industrial investment was R\$ 135.00 per ton of industrial processing capacity. The premise for cogeneration investment was $\mathrm{R} \$ 60.00$ per ton of industrial processing capability. The depreciation estimative uses the criterion of linear depreciation, 30 years for investment in sugar and ethanol, and 20 years for cogeneration. The actual interest rate considered is $6 \%$ per year and the land opportunity cost is set by the amount of lease charged.

(4) Grinding nominal capacities were three million tons for traditional and expansion regions and 1.5 million for the Northeast region. The production cost per unit of product, i.e., actual spending on each ton of sugar produced or $\mathrm{R} \$ / \mathrm{m}^{3}$ of ethanol, is estimated using Eq. (1).

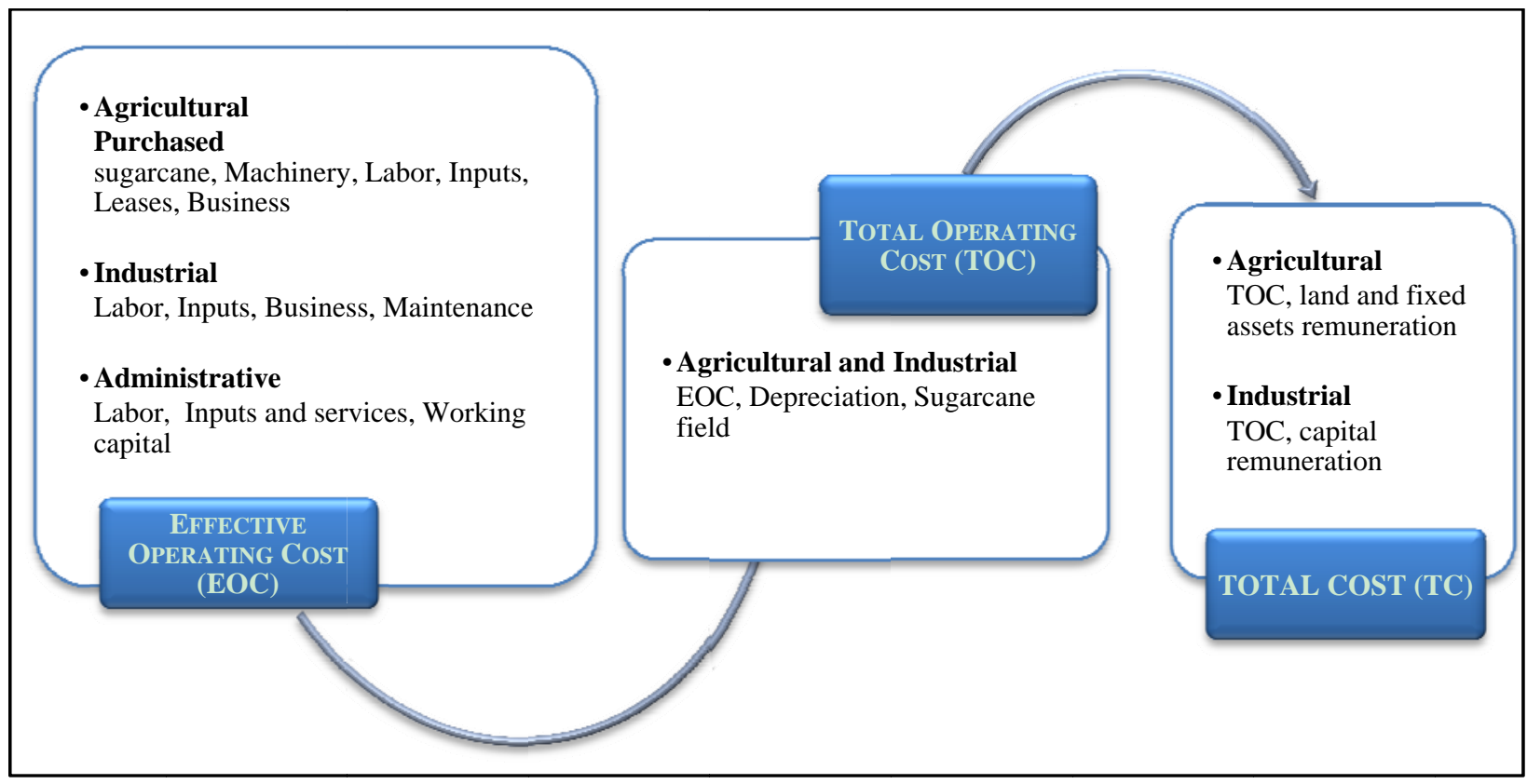

Figure 4. Summary of the agroindustrial costs’ standard allocation. Source: Pecege (2015).

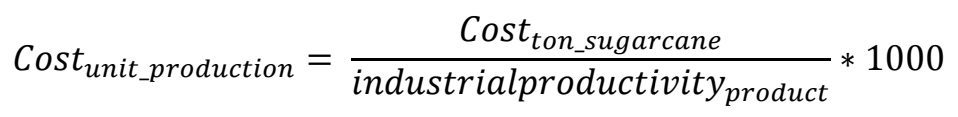

Cost indicators "CONSECANA payment” and "packing costs of industrial products" are exceptions that cannot use the criterion of transformation shown in Eq. (1). To solve the first exception, it is estimated a price paid by different sugarcane for each product produced. It is important to notice that the subsidy costs paid by sugarcane follow Eq. (1) calculation assumptions. However, the cost of packaging is calculated by dividing the result calculated using Eq. (1) by the mix of white sugar production and attaching all of these costs to white sugar, while the packaging costs are zero for all other products.

\section{Data}

The database used for this work consists of primary data collected through questionnaires in interviews, and field visits to Brazilian agroindustrial units and to sugarcane growers. The survey information is part of the 
university extension project "Survey System of Agricultural Production Cost and Sugarcane Industry in Brazil”, which is performed by PECEGE extension group-Program of Continuing Education in Economics and Management in a partnership established between CNA-Brazilian Confederation of Agriculture and Livestock and FEALQ—Fundação de Estudos Agrários “Luiz de Queiroz” (Foundation of Agrarian Studies "Luiz de Queiroz”) since 2008, whose methodology is detailed in Xavier, Zilio, Sonoda and Marques (2009).

In order to determine the production costs of growers' sugarcane, it followed the methodology of "panels", characterized by face meetings, in which participants, who are usually farmers and cooperatives technicians, associations and unions, define consensually modal manufacturing facility in the particular region, indicating the technical and economic coefficients predetermined to define the technological package for sugarcane production.

However, questionnaires were applied from the Brazilian agroindustrial units to obtain the own sugarcane cost indicators, as well as the main products, sugar, and ethanol. The sample is not random, since the application criteria for the interview and the questionnaire were the industrial representative of agribusiness in your area, then the receptivity of the company's management to make the information requested in the survey questionnaires available.

\section{Research Results}

\section{Production Costs of Independent Growers' Sugarcane}

The main technical/economic indicators of production, such as production costs, calculated between 2007/08 and 2013/14 crop seasons for the macro-models are shown in Table 1 and Table 2 respectively. In a comparative technical-economic analysis of the regions, the main aspects are observed:

- TRADITIONAL CENTRAL-SOUTH: (i) the main differences in production costs among regions occur following land remuneration and other costs, usually from administrative origin. In the case of land remuneration, the values are based on lease agreements, which in traditional region are relatively higher compared to other regions, indicating greater competition for land; (ii) the proportion of mechanized harvesting continues to rise around $80 \%$ in the $2013 / 2014$ crop season. This growth trend is the result of the production overview, characterized by restrictions on burning before the harvest. Mechanized planting, however, has not yet been verified in the analysis period with the traditional region growers.

- EXPANSION CENTRAL-SOUTH: (i) the scale of sugarcane agricultural production is considerably higher in the Expansion region which areas are 550 hectares. In Traditional and Northeast regions, the range is 170 ha and 145 ha, respectively; (ii) the administrative structure costs are inversely proportional to the production scale. In the Expansion region, these costs are relatively lower. It is important to observe the producer versatility of this region, which in general, also grows other kinds of culture, for example soybeans and corn. This situation contributes to the dilution of fixed costs (administrative expenses and common machinery) and its apportionment among the different cultures; and (iii) high levels of mechanization: the harvest is completely performed by machines and advanced mechanized planting, reaching levels around $80 \%$ in the 2013/14 crop season.

- NORTHEAST: (i) the Northeast had the highest ATR price (R $\$ / \mathrm{kg}$ ATR), in order to have a strong sugar character of the mills, the existence of export quotas for VHP sugar, and local market conditions of sugar and ethanol prices higher than in other regions; (ii) intensive labor in the production process, with not verified mechanized planting and harvest indexes. The fully manual method is restricted to high slope areas prevalent in the Northeast; and (iii) agricultural productivity at lower levels-around 55 t/ha-when compared to 
Central-South region, whose yields were around 80 t/ha over the crops. This is the big difference as you compare the production costs among regions.

Table 1

Progress of the Main Technical Indicators of Sugarcane Production for Growers, Considering Macro Regional Research Segmentation (Traditional Central-South, Expansion Central-South, and Northeast)

\begin{tabular}{|c|c|c|c|c|c|c|c|c|}
\hline \multirow[t]{2}{*}{ Panel } & \multirow[t]{2}{*}{ Crop season } & Area & $\begin{array}{l}\text { Average } \\
\text { productivity* }\end{array}$ & \multirow{2}{*}{$\begin{array}{l}\text { ATR } \\
\mathrm{kg} / \mathrm{t}\end{array}$} & \multirow{2}{*}{$\begin{array}{l}\text { ATR price } \\
\text { R\$/kg ATR }\end{array}$} & \multirow{2}{*}{$\begin{array}{l}\text { Mechanized } \\
\text { harvest } \\
\%\end{array}$} & \multirow{2}{*}{$\begin{array}{l}\text { Mechanized } \\
\text { planting } \\
\%\end{array}$} & \multirow{2}{*}{$\begin{array}{l}\text { Lease } \\
\text { t/ha }\end{array}$} \\
\hline & & ha & t/ha & & & & & \\
\hline \multirow{7}{*}{ Traditional } & $07 / 08$ & 170 & 84 & 143 & 0.2443 & 45 & 0 & 15 \\
\hline & 08/09 & 170 & 89 & 139 & 0.2782 & 65 & 0 & 18 \\
\hline & 09/10 & 170 & 84 & 129 & 0.3492 & 65 & 0 & 18 \\
\hline & $10 / 11$ & 170 & 83 & 137 & 0.4019 & 65 & 0 & 18 \\
\hline & $11 / 12$ & 170 & 74 & 140 & 0.5018 & 65 & 0 & 21 \\
\hline & $12 / 13$ & 170 & 77 & 136 & 0.4728 & 65 & 0 & 21 \\
\hline & $13 / 14$ & 170 & 80 & 133 & 0.4572 & 80 & 0 & 21 \\
\hline \multirow{7}{*}{ Expansion } & $07 / 08$ & 550 & 84 & 145 & 0.2443 & 35 & 0 & 12 \\
\hline & 08/09 & 550 & 84 & 139 & 0.2782 & 45 & 0 & 12 \\
\hline & 09/10 & 550 & 80 & 130 & 0.3492 & 65 & 0 & 12 \\
\hline & $10 / 11$ & 550 & 84 & 138 & 0.4019 & 95 & 0 & 12 \\
\hline & $11 / 12$ & 550 & 78 & 140 & 0.5018 & 100 & 50 & 12 \\
\hline & $12 / 13$ & 550 & 81 & 135 & 0.4728 & 100 & 75 & 13 \\
\hline & $13 / 14$ & 550 & 84 & 133 & 0.4572 & 100 & 80 & 13 \\
\hline \multirow{7}{*}{ Northeast } & $07 / 08$ & 145 & 56 & 138 & 0.2722 & 0 & 0 & 8 \\
\hline & 08/09 & 145 & 57 & 139 & 0.3377 & 0 & 0 & 8 \\
\hline & 09/10 & 145 & 51 & 133 & 0.4567 & 0 & 0 & 8 \\
\hline & $10 / 11$ & 145 & 58 & 129 & 0.5642 & 0 & 0 & 8 \\
\hline & $11 / 12$ & 145 & 58 & 133 & 0.5448 & 0 & 0 & 8 \\
\hline & $12 / 13$ & 145 & 50 & 137 & 0.5327 & 0 & 0 & 8 \\
\hline & $13 / 14$ & 145 & 52 & 126 & 0.5408 & 0 & 0 & 8 \\
\hline
\end{tabular}

Note. ${ }^{*}$ Considering the production cycle of 5 cuts.

Table 2

Progress of Nominal Production Costs of Sugarcane by Stage, Under Growers' Perspective, Considering Macro Regional Research Segmentation (Traditional Central-South, Expansion Central-South, and Northeast)

\begin{tabular}{|c|c|c|c|c|c|c|c|c|}
\hline \multirow[t]{2}{*}{ Panel } & \multirow[t]{2}{*}{ Crop season } & Tillage & Planting & $\begin{array}{l}\text { Plant } \\
\text { treatment }\end{array}$ & $\begin{array}{l}\text { Ratoon } \\
\text { treatment }\end{array}$ & Harvest & Administrative & Others* \\
\hline & & $\mathrm{R} \$ / \mathrm{ha}$ & $\mathrm{R} \$ / \mathrm{ha}$ & $\mathrm{R} \$ / \mathrm{ha}$ & $\mathrm{R} \$ / \mathrm{ha}$ & $\mathrm{R} \$ / \mathrm{t}$ & $\mathrm{R} \$ / \mathrm{ha}$ & $\mathrm{R} \$ / \mathrm{ha}$ \\
\hline \multirow{7}{*}{ Traditional } & 07/08 & 985.27 & $1,747.46$ & 257.52 & 839.74 & 14.69 & 204.27 & 259.54 \\
\hline & 08/09 & 953.54 & $2,100.53$ & 274.83 & 860.61 & 16.67 & 218.58 & 241.32 \\
\hline & 09/10 & $1,089.06$ & $2,404.83$ & 287.01 & 770.30 & 19.70 & 225.88 & 305.13 \\
\hline & $10 / 11$ & $1,160.92$ & $2,547.68$ & 292.81 & 830.03 & 21.33 & 240.77 & 282.81 \\
\hline & $11 / 12$ & $1,148.92$ & $2,704.51$ & 301.29 & $1,085.39$ & 23.20 & 264.66 & 357.36 \\
\hline & $12 / 13$ & $1,359.51$ & $3,102.18$ & 338.02 & $1,102.35$ & 25.27 & 273.20 & 375.30 \\
\hline & $13 / 14$ & $1,384.54$ & 3,003.39 & 416.39 & $1,116.84$ & 25.42 & 273.59 & 375.30 \\
\hline \multirow{4}{*}{ Expansion } & 07/08 & 768.50 & $1,813.39$ & 286.46 & 744.65 & 15.69 & 167.10 & 104.12 \\
\hline & 08/09 & 816.36 & $2,004.74$ & 293.25 & 766.59 & 17.17 & 174.84 & 85.71 \\
\hline & 09/10 & 874.16 & 2,338.13 & 288.49 & 872.81 & 17.88 & 184.76 & 122.43 \\
\hline & $10 / 11$ & 889.85 & 2,618.39 & 278.15 & 834.07 & 17.08 & 209.13 & 102.03 \\
\hline
\end{tabular}


Table 2 to be continued

\begin{tabular}{lllllllll}
\hline \multirow{2}{*}{ Expansion } & $11 / 12$ & 942.69 & $3,158.15$ & 298.92 & 957.83 & 20.10 & 225.34 & 136.05 \\
& $12 / 13$ & $1,045.95$ & $3,401.86$ & 263.05 & $1,015.29$ & 22.80 & 224.17 & 114.74 \\
& $13 / 14$ & $1,096.14$ & $3,533.74$ & 273.76 & $1,035.76$ & 24.06 & 228.41 & 127.45 \\
\hline \multirow{5}{*}{ Northeast } & $07 / 08$ & 834.99 & $2,219.25$ & 418.16 & 710.71 & 18.82 & 178.65 & 236.78 \\
& $08 / 09$ & 825.06 & $2,486.65$ & 407.06 & 804.29 & 19.73 & 189.84 & 290.64 \\
& $109 / 10$ & 872.56 & $2,744.29$ & 409.21 & 701.73 & 20.43 & 214.47 & 286.86 \\
& $11 / 12$ & 871.67 & $3,102.48$ & 429.32 & 698.98 & 23.24 & 245.48 & 260.88 \\
& $12 / 13$ & 951.57 & $3,276.41$ & 469.68 & 784.65 & 24.53 & 246.40 & 280.66 \\
& $13 / 14$ & $1,032.61$ & $3,285.31$ & 557.31 & $1,081.09$ & 28.72 & 234.21 & 260.88 \\
\hline
\end{tabular}

Note. * Others: Lease + administrative expenses + working capital + improvement depreciation and irrigation + owner remuneration + capital remuneration.

In profitability activity analysis of sugarcane (Figure 5), when the production costs were compared with the prices, the diagnosis is made from two perspectives: Total Operating Cost (TOC) and Total Cost (TC). The difference from the second to the first is limited to the incorporation of capital opportunity costs. In a simplified analysis, TOC and TC represent, respectively, the economic viability of the activity in the horizons of medium and long term.

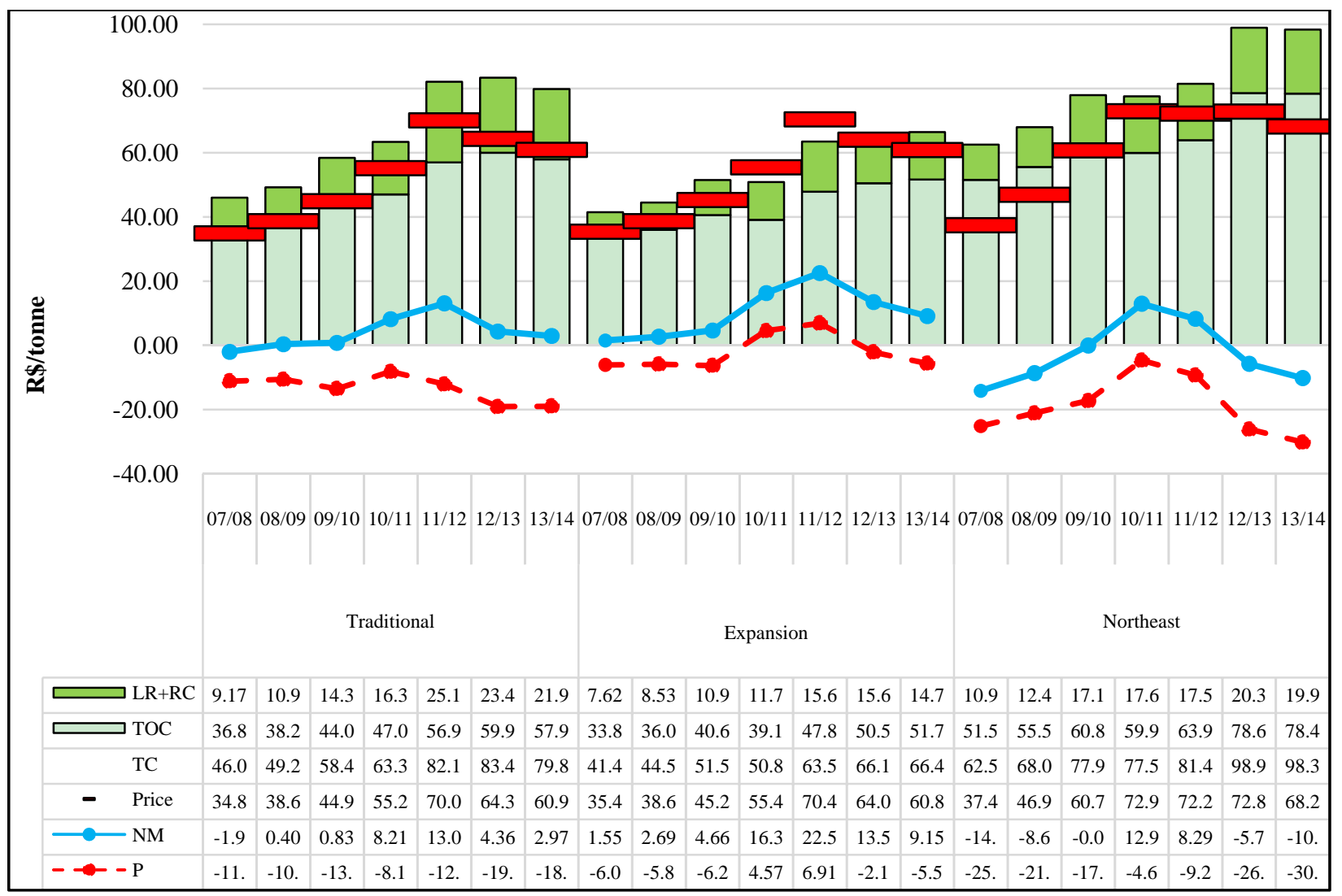

Figure 5. Progress of prices, costs and margins (deflated) for sugarcane production of growers' sugarcane, considering macro regional research segmentation (Traditional Central-South, Expansion Central-South and Northeast). Notes. * LR + RC - Land Remuneration + Return on Capital; TOC - Total operating cost; TC - Total cost; NM - Net margin; P - Profit; ${ }^{* *} \mathrm{NM}=$ Price $-\mathrm{TOC}$; $\mathrm{P}=$ Price $-\mathrm{TC}$. 
Since 2011/2012 crop season, is a deterioration of growers' sugarcane economic margins in all regions, the prices received for sugarcane in Traditional region were sufficient to cover all operating production costs, including depreciation, but failed to overcome the total costs. A comparative analysis between the Traditional Central-South and Expansion, the main differences in costs composition are associated with agricultural productivity and production scale, in addition to the apportionment of fixed expenses with other cultures besides sugarcane.

It observed an increase in nominal production costs that were not accompanied by sugarcane prices (Figure 5). In the last two analyzed crop seasons, reductions in margins were mainly due to lower agricultural productivity. In total costs analysis, i.e. incorporating capital costs to operating costs, there is a loss to all regions analyzed, except for the Expansion Central-South region in 2010/11 and 2011/12 crop seasons.

Under a new perspective to analyze the real profitability of R $\$ / \mathrm{kg}$ ATR (Figure 6), the Central-South region showed positive net margin in almost every year of the survey, which indicates economic viability in medium term, however low attractiveness in long term, since the profit values were negative. The Northeast region presents a more delicate situation, and in only two occasions, the margin was higher than zero, indicating a low attractiveness to the activity in the medium and long term.

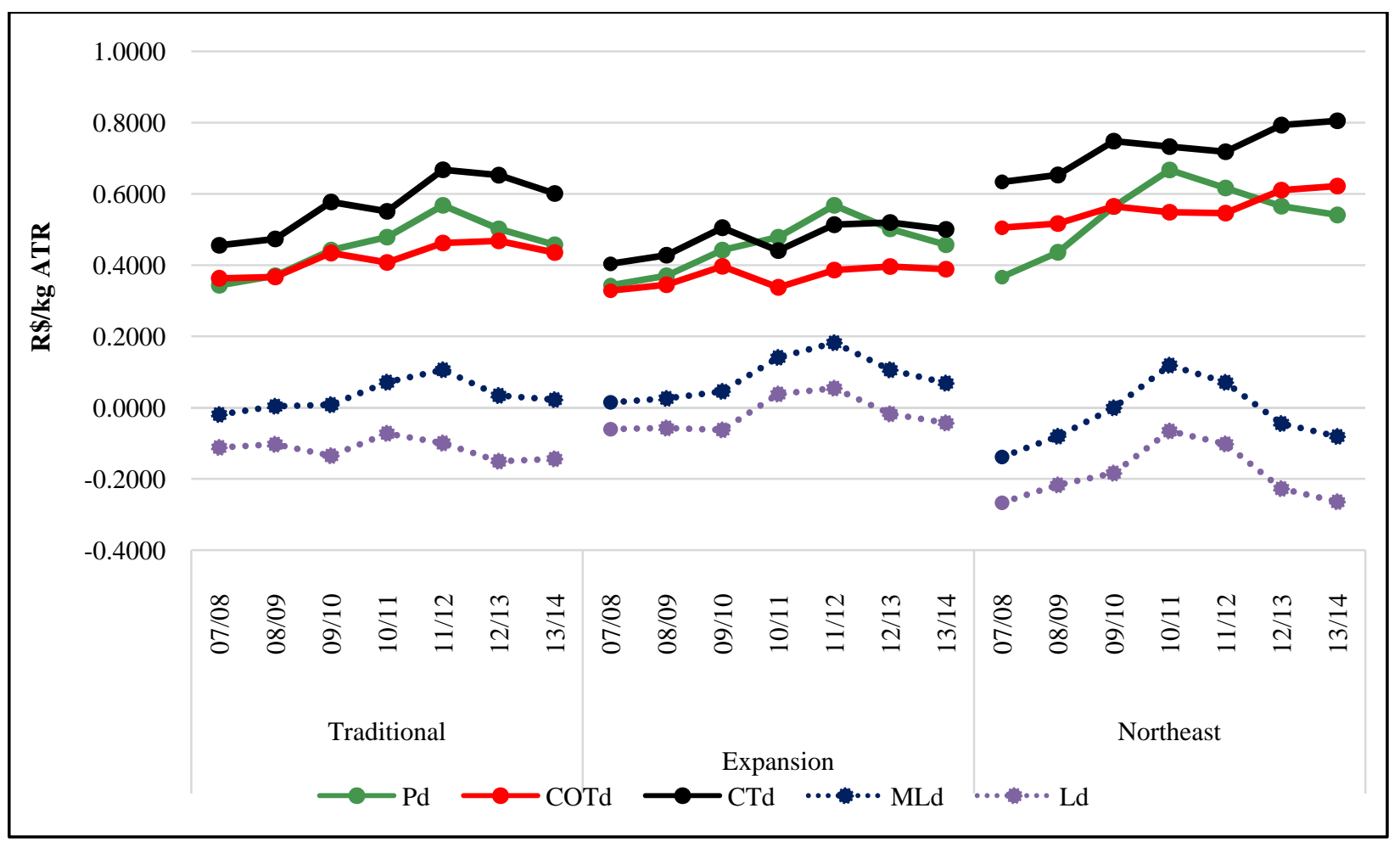

Figure 6. Progress of prices, costs and margins (deflated) for sugarcane production of growers' sugarcane, considering macro regional research segmentation (Traditional Central-South, Expansion Central-South and Northeast). Notes. * Priced—Deflated price; TOCd—Total deflated operating cost; TCd—Deflated total cost; NMd—Deflated net margin; Pd—Deflated profit; ** NMd = Priced - TOCd; Pd = Priced - TCd.

However, from the technological overview, in all regions, the deflated operating cost (R $\$ / \mathrm{kg}$ ATR) is inversely proportional to the productivity, i.e. the most productive sugarcane field is those that have the smaller operating costs (Figure 7). Therefore, the maintenance of productive sugarcane can contribute to increasing 
profitability. Not always all the factors of production are under the tutelage of producer as is the case of climatic factors (rainfall, temperature, and wind), but the renewal of the plantation, cultivation, and care with the harvest may distinguish it in an improved perspective of productivity.

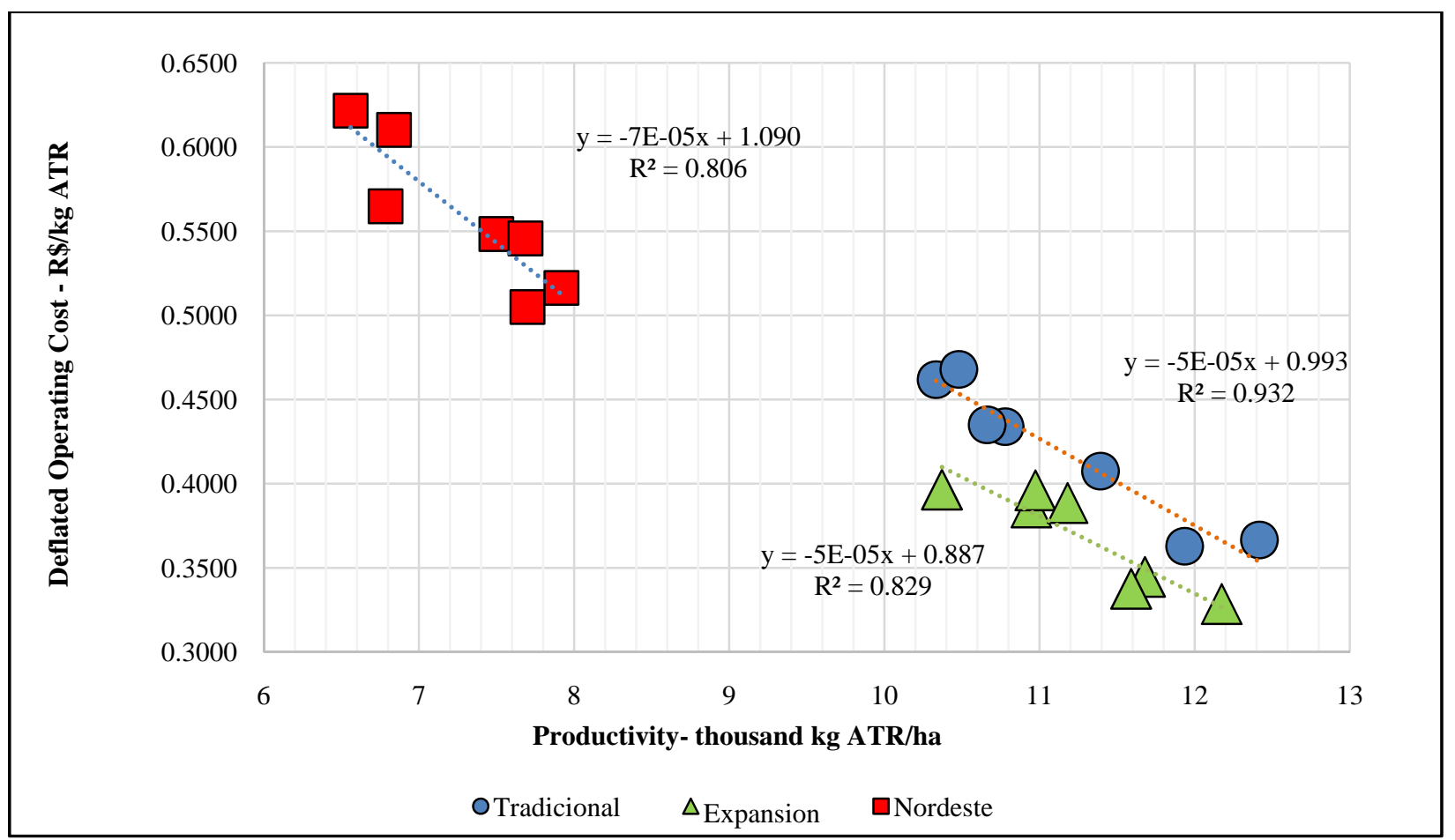

Figure 7. Relation between deflated operating cost (R $/ \mathrm{kg}$ ATR) and ATR productivity (thousand kg/ha), for sugarcane production by growers, considering macro regional research segmentation (Traditional Central-South, Expansion Central-South, and Northeast).

\section{Cost Calculation of Industrial Production (Sugar and Ethanol)}

Total cost (TC) results of agroindustrial production, following the methodology presented, are arranged from Table 3 to 8. These tables present price values and costs of the last crops, deflated by IGP-DI (General Price Index-Internal Availability) based on March $2015^{6}$ and the annual average variation since 2007/2008 crop season.

All production costs analyzed present real development between 2007/08 and 2014/15 crops. The own sugarcane production costs in Traditional region increased by about $6.1 \%$ per year in the period analyzed, while the actual price paid for sugarcane suppliers increased by 3.9\% per year. In this region, the production cost of the own sugarcane has been more expensive than the costs to acquire suppliers. Additionally, it is important to observe that the agroindustrial processing costs of sugarcane have grown at a higher rate than the final products prices of Brazilian sugar-energy industry.

Table 3 points the development of the price paid to sugarcane suppliers by the CONSECANA method, i.e. the amounts related to the bonus paid to suppliers are not included in the indicated prices.

\footnotetext{
${ }^{6}$ Base March, 2015. For deflating the harvest average, the IGP-DI was added according to the 12 months of the crop season. The value of the IGP-DI refers to the amount accumulated during the months of April and March of the following year. For example, the IGP-DI for the $2014 / 2015$ crop season was estimated at $3.5 \%$ and corresponded to the accumulated IGP-DI between the months from April 2014 to March 2015.
} 
Table 3

CONSECANA Price Development Paid for Growers' Sugarcane in R\$/t-R\$ of 2015

\begin{tabular}{|c|c|c|c|c|c|c|c|c|c|}
\hline \multirow{2}{*}{ Region } & \multicolumn{8}{|c|}{ Crop season } & \multirow{2}{*}{ - \% annual } \\
\hline & $2007 / 08$ & $2008 / 09$ & $2009 / 10$ & $2010 / 11$ & $2011 / 12$ & $2012 / 13$ & $2013 / 14$ & $2014 / 15$ & \\
\hline Expansion & 51.38 & 55.93 & 62.07 & 67.70 & 79.25 & 71.56 & 65.83 & 64.19 & $3.5 \%$ \\
\hline Traditional & 50.62 & 55.72 & 61.56 & 72.76 & 85.95 & 73.79 & 65.05 & 65.60 & $3.9 \%$ \\
\hline Northeast & 54.32 & 67.59 & 83.29 & 93.44 & 84.14 & 82.73 & 73.93 & 70.53 & $2.6 \%$ \\
\hline
\end{tabular}

Table 4

Development Costs of Mills' Own Sugarcane Production in $R \$ / t-R \$$ de 2015

\begin{tabular}{llllllllll}
\hline \multirow{2}{*}{ Region } & \multicolumn{10}{c}{ Crop season } \\
\cline { 2 - 9 } & $2007 / 08$ & $2008 / 09$ & $2009 / 10$ & $2010 / 11$ & $2011 / 12$ & $2012 / 13$ & $2013 / 14$ & $2014 / 15$ & \\
\hline Expansion & 69.56 & 66.13 & 65.59 & 62.27 & 84.28 & 89.03 & 84.67 & 86.92 & $4.8 \%$ \\
Traditional & 61.73 & 66.16 & 65.27 & 70.99 & 92.21 & 90.53 & 86.28 & 89.03 & $6.1 \%$ \\
Northeast & 79.11 & 86.52 & 80.48 & 83.85 & 88.74 & 109.24 & 97.10 & 96.01 & $3.5 \%$ \\
\hline
\end{tabular}

Table 5

Development Costs of White Sugar Production in $R \$ / t-R \$$ de 2015

\begin{tabular}{|c|c|c|c|c|c|c|c|c|c|}
\hline \multirow{2}{*}{ Region } & \multicolumn{8}{|c|}{ Crop season } & \multirow{2}{*}{-\% annual } \\
\hline & $2007 / 08$ & $2008 / 09$ & $2009 / 10$ & $2010 / 11$ & $2011 / 12$ & $2012 / 13$ & $2013 / 14$ & $2014 / 15$ & \\
\hline Expansion & 752 & 831 & 895 & 826 & 1,055 & 1,001 & 970 & 1,046 & $4.4 \%$ \\
\hline Traditional & 718 & 792 & 968 & 877 & 1,115 & 988 & 991 & 979 & $4.3 \%$ \\
\hline Northeast & 913 & 901 & 987 & 1,030 & 1,068 & 1,125 & 1,105 & 1,081 & $3.1 \%$ \\
\hline
\end{tabular}

Table 6

Development Costs of VHP Sugar Production in $R \$ / t-R \$$ de 2015

\begin{tabular}{llllllllll}
\hline \multirow{2}{*}{ Region } & \multicolumn{8}{c}{ Crop season } \\
\cline { 2 - 9 } & $2007 / 08$ & $2008 / 09$ & $2009 / 10$ & $2010 / 11$ & $2011 / 12$ & $2012 / 13$ & $2013 / 14$ & $2014 / 15$ & \\
\hline Expansion & 722 & 798 & 847 & 783 & 979 & 972 & 942 & 975 & $4.3 \%$ \\
Traditional & 680 & 754 & 850 & 820 & 1,026 & 972 & 942 & 943 & $4.8 \%$ \\
Northeast & 888 & 880 & 970 & 996 & 999 & 1,080 & 1,080 & 1,033 & $2.9 \%$ \\
\hline
\end{tabular}

Table 7

Development Costs of Anhydrous Ethanol Production in $R \$ / m^{3}-R \$$ de 2015

\begin{tabular}{|c|c|c|c|c|c|c|c|c|c|}
\hline \multirow{2}{*}{ Region } & \multicolumn{8}{|c|}{ Crop season } & \multirow{2}{*}{ \% annual } \\
\hline & $2007 / 08$ & 2008/09 & $2009 / 10$ & 2010/11 & 2011/12 & 2012/13 & $2013 / 14$ & $2014 / 15$ & \\
\hline Expansion & 1,217 & 1,380 & 1,396 & 1,270 & 1,603 & 1,554 & 1,559 & 1,605 & $3.7 \%$ \\
\hline Traditional & 1,169 & 1,305 & 1,427 & 1,309 & 1,673 & 1,546 & 1,552 & 1,579 & $4.1 \%$ \\
\hline Northeast & 1,498 & 1,533 & 1,633 & 1,651 & 1,698 & 1,837 & 1,828 & 1,740 & $2.7 \%$ \\
\hline
\end{tabular}

Table 8

Development Costs of Hydrous Ethanol Production in $R \$ / m^{3}-R \$$ de 2015

\begin{tabular}{llllllllll}
\hline \multirow{2}{*}{ Region } & \multicolumn{10}{c}{ Crop season } & \% annual \\
\cline { 2 - 9 } & $2007 / 08$ & $2008 / 09$ & $2009 / 10$ & $2010 / 11$ & $2011 / 12$ & $2012 / 13$ & $2013 / 14$ & $2014 / 15$ & $3.7 \%$ \\
Expansion & 1,144 & 1,290 & 1,322 & 1,189 & 1,519 & 1,458 & 1,463 & 1,512 & $4.3 \%$ \\
Traditional & 1,092 & 1,211 & 1,324 & 1,229 & 1,571 & 1,444 & 1,459 & 1,482 & $2.7 \%$ \\
Northeast & 1,422 & 1,455 & 1,550 & 1,567 & 1,611 & 1,744 & 1,735 & 1,651 & 2.75 \\
\hline
\end{tabular}


In order to understand better the development for agroindustrial costs of sugarcane processing, Figure 8 shows the evolution of agroindustrial costs with the average productivity of sugarcane plantation for the three regions between 2007/08 and 2014/15 crops.

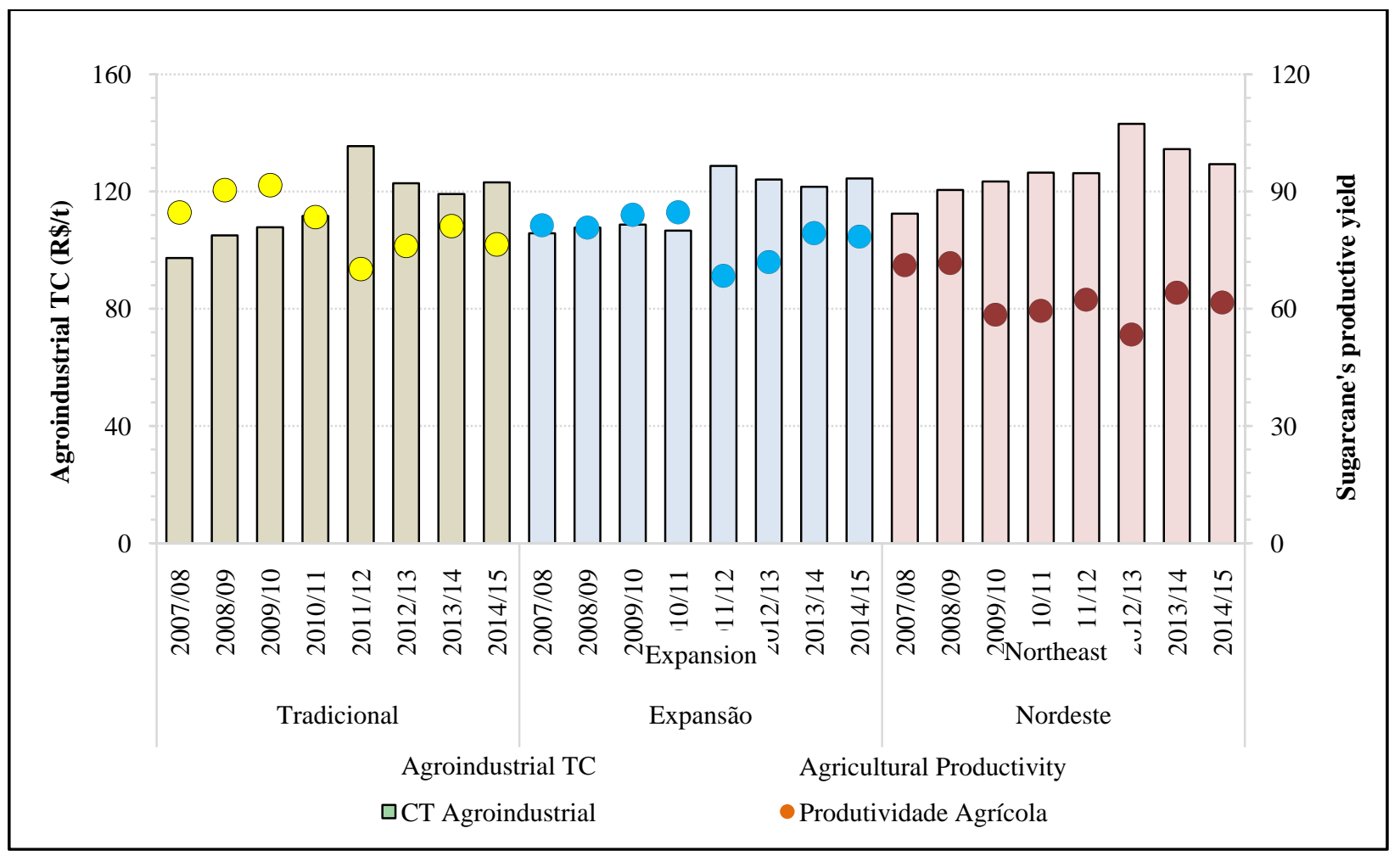

Figure 8. Changes in the total agroindustrial processing costs of sugarcane and value of standing cane (estimated yield, quantity of sugar per ton of cane, value of sugar and other), considering macro regional research segmentation (Traditional, Expansion, and Northeast). Note. TC agroindustrial (2015 Brazilian Reais).

The total cost of processing sugarcane increased 3.4\% p.a., 2.8\% p.a., and 2.3\% p.a., respectively for the Traditional, Expansion, and Northeast regions. In the same period, the average productivity of sugarcane area declined $2.4 \%$ p.a., $1.2 \%$ p.a., and $2.1 \%$ p.a. for the respective regions.

The reduction in profitability over the last crops has reduced the ability of the mills in continuing investing in production and, consequently, in the sugarcane quality. The direct impact is the reduction in agricultural productivity, which leads to increased agribusiness costs, further reducing profitability. Despite the expectation of climate improvement for the next crop, reducing the ATR processed sugarcane at $0.9 \%$ p.a. in Traditional region and 1.6\% p.a. in Expansion region shows that the sugarcane plantations of Central-South region offers less sugar per hectare each crop. Thus, it is evident that the industry will return to profitability only if increases the productivity of its sugarcane plantations through new investments associated with the favorable macroeconomic perspectives.

\section{Conclusions}

Sugarcane production as an economic activity is under to a multitude of variables that can affect their profitability. This paper shows, the past crop seasons, the average values of the production costs for each of the sampled regions. 
Although the average situation is not very promising, it is essential to emphasize that some producers distinguish and earn income in this agricultural activity. This study brings some indication of the main variables, impact on production costs, and it has the effect of the most significant productivity. Furthermore, it reinforces the need for producers having increasingly more control over their activity, as a way to increase their profitability by reducing its production cost, which may be further conducted if previously known.

The main highlight survey results and points of sugarcane, sugar, ethanol, and bioelectricity production costs in Brazil, for the 2014/15 crop season are: (i) the decrease in agricultural productivity resulted in increased costs in the regions; (ii) sugarcane costs produced by the mill are higher than the potential price in all regions, highlighting the advantage of mills which acquired more sugarcane from the suppliers; (iii) costs with "cultivation of ratoon cane" increased in all regions as a result of higher sugarcane input prices, such as fertilizers; (iv) in the 2014/15 crop season, all industrial products recorded negative economic margins in all three geographical regions (the price paid for sugar was enough to pay the agroindustrial TOC of mills from all regions, for anhydrous ethanol, this is only for Traditional and Northeast regions, and hydrous ethanol, just to the Northeast); and (v) the mills which sold electricity in the 2014/15 crop obtained additional revenues that contributed to facilitating the attractiveness deterioration and sugar and ethanol production results.

This paper on the production costs of sugarcane, sugar, ethanol, and bioelectricity enhances the commitment to spread indicators, tools, and cost calculation methods. It is expected that the results and analysis presented support the decisions of agents of Brazilian sugar-energy sector, which at that time, need good information and analysis that can support the actions for improvement in its management and planning practices.

\section{References}

Bastos, A. C. (2013). Fornecimento de Cana-de-Açúcar e Integração Vertical no Setor Sucroenergético do Brasil. Dissertação (Mestrado em Economia Aplicada)—Escola Superior de Agricultura Luiz de Queiroz, Universidade de São Paulo, Piracicaba, SP.

Brasil, Ministério de Minas e Energia. (2010). Balanço Energético Nacional 2011. Available in: <https://ben.epe.gov.br/benrelatoriofinal2011.aspx>. Visited on: 24 out. 2015.

BRASIL, Ministério da Agricultura, Pecuária e Abastecimento. Secretaria de Produção e Agroenergia. (2015). Anuário Estatístico da Agroenergia 2014. Brasília, DF, 205.

Instituto Brasileiro de Geografia e Estatística. (2015). Sistema de Recuperação Automática (SIDRA). Retrieved from $<$ http://www.sidra.ibge.gov.br/>

Matsunaga, M., et al. (1976). Metodologia de custo de produção utilizada pelo IEA. Agricultura em São Paulo, 23(1), 123-139.

Neves, M. F., \& Conejero, M. A. (2007). Sistema agroindustrial da cana: cenários e agenda estratégica. Revista de Economia Aplicada, 11(4), 587-604.

Pecege. (2015). Custos de produção de cana-de-açúcar, açúcar, etanol e bioeletricidade no Brasil: Fechamento da safra 2014/2015. Piracicaba, SP. Universidade de São Paulo, Escola Superior de Agricultura "Luiz de Queiroz”, Programa de Educação Continuada em Economia e Gestão de Empresas. Relatório apresentado à Confederação da Agricultura e Pecuária do Brasil-CNA.

Pereira Filho, C. A. (2000). Eficiência econômica da pequena produção familiar no Recôncavo do Estado da Bahia: uma análise não paramétrica de fronteiras de produção multi-produto. Tese (Doutorado)—Escola Superior de Agricultura Luiz de Queiroz, Universidade de São Paulo, Piracicaba.

Pinto, M. J. A. (2011). Investimentos diretos estrangeiros no setor sucroenergético. Dissertação (Mestrado em Administração em Organizações)—Faculdade de Economia, Administração e Contabilidade de Ribeirão Preto, Universidade de São Paulo, Ribeirão Preto.

Satolo, L. F. (2008). Dinâmica econômica das flutuações na produção de cana-de-açúcar. Dissertação (Mestrado em Economia Aplicada)-Escola Superior de Agricultura “Luiz de Queiroz”. Universidade de São Paulo, Piracicaba. 
Siqueira, P. H. L, \& Castro Júnior, L. G. C. (2010). Fusões e Aquisições das Unidades Produtivas e da Agroindústria de Cana-de-açúcar no Brasil e nas Distribuidoras de Álcool Hidratado Etílico. Revista de Economia e Sociologia Rural, 48(4), 709-735.

Xavier, C. E. O., Zilio, L. B., Sonoda, D. Y., \& Marques, P. V. (2009). Custos de produção de cana-de-açúcar, açúcar e etanol no Brasil: safra 2008/2009. Piracicaba, SP. Universidade de São Paulo, Escola Superior de Agricultura "Luiz de Queiroz”, Programa de Educação Continuada em Economia e Gestão de Empresas. Relatório apresentado à Confederação da Agricultura e Pecuária do Brasil-CNA. 